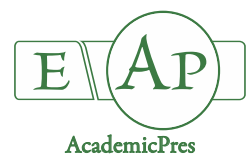

\title{
GC-MS Analysis, Antioxidant, Antimicrobial and Anticancer Activities of Extracts from Ficus sycomorus Fruits and Leaves
}

\author{
Hossam S. EL-BELTAGI ${ }^{1,2 *}$, Heba I. MOHAMED ${ }^{3}$, \\ Abdelrahman S. ABDELAZEEM ${ }^{4}$, Reem YOUSSEF ${ }^{4}$, Gehan SAFWAT ${ }^{4}$ \\ ${ }^{1}$ Cairo University, Faculty of Agriculture, Biochemistry Department, Giza, Cairo, Egypt; helbeltagi@agr.cu.edu.eg (*correspondingauthor) \\ ${ }^{2}$ Cairo University, Research Park (CURP), Giza, Cairo, Egypt \\ ${ }^{3}$ Ain Shams University, Faculty of Education, Department of Biological and Geological Science, Cairo, Egypt; bebaibrahim79@gmail.com \\ ${ }^{4}$ October University for Modern Science and Art (MSA), Faculty of Biotechnology, Egypt; abdelrhman.salah@msa.edu.eg; \\ Reem.youssef@msa.edu.eg; gehan.safwat@hotmail.co.uk
}

\begin{abstract}
Higher plants have been utilized worldwide as characteristic drug a long time to cure human diseases. About $80 \%$ of individuals globally use plants as safe sources of medication to cure human diseases through completely different medicine system. One of the available indigenous medicinal plants, Ficus sycomorus belongs to the Moraceae family. The plant contains totally different teams of biologically active compounds that square measure chargeable for the biological activity. Ethanolic and ethyl acetate extracts of leaves of Ficus sycomorus contain higher concentrations of total phenols, flavonoids, tannins, alkaloids and steroids than the fruit extracts. Ethanolic extract in both fruits and leaves gave higher concentrations of phytochemical compounds than the ethyl acetate extracts. Therefore, fruit and leaves extract have antioxidant and antimicrobial activity against gram positive, negative bacteria and fungus. Also, the percentage of Liver cell line (HepG2), Colorectal adenocarcinoma (Caco-2) and Breast cell line (MCF-7) viability was decreased with increasing the concentrations of the ethanolic extract of fruits and leaves of Ficus sycomorus. The high concentrations of ethanolic extract of fruits caused high reduction in the viability of cancer cells, especially in Colorectal adenocarcinoma (Caco-2) cell line. In addition, phytochemical compound screened by GC-MS method. In GC-MS analysis, 12 bioactive phytochemical compounds were identified in fruits and 29 bioactive compounds were detected in leaves extract. These totally different active phytochemicals are found to possess a good vary of activities, which can facilitate within the protection against incurable diseases.
\end{abstract}

Keywords: antibacterial; anticancer activity; DPPH; fatty acids; flavonoids; phenols; steroids

\section{Introduction}

Ficus sycomorus is a short tree that belongs to the Moraceae family. It is native to Africa. Its fruit is called figs, which have been used as food and medicine. Locally, it is called 'subula', and it is widely distributed in the Mediterranean basin of Egypt and called 'sycamore' or 'gimmeiz'. Among the important medicinal plants are species that belong to Moraceae, often called the mulberry family or fig family. This is a family of flowering plants comprising approximately 40 genera and over 1000 species. Most are widespread in tropical and subtropical regions (Van et al., 2007). The height of $F$. sycomorus is approximately $20 \mathrm{~m}$ and $6 \mathrm{~m}$ wide. The fruit is large, approximately $2-3 \mathrm{~cm}$ in diameter, maturing from buffgreen to yellow or red. The bark is a green or yellow to orange colour. The leaves are heart-shaped with a spherical apex. They are $14 \mathrm{~cm}$ tall and $10 \mathrm{~cm}$ broad. Also, their margin is entire. The flower is spherical, greenish, and unisexual. It contains latex, like all other figs (Romeh, 2013). The fruits of F. sycomorus are an important herbal medicine and food that is used to treat fungal infections, jaundice and dysentery (Hassan et al., 2007). In addition, it is used for the treatment of cough, diarrhea, skin infection, stomach disorders, liver disease, epilepsy, tuberculosis, lactation disorders, helminthiasis, infertility and sterility (Sandabe et al., 2006). The extracts of fruits of F. sycomorus are also used for the treatment of various diseases, such as cough, diarrhea, stomach disorder, skin infections, epilepsy, liver disease, tuberculosis, lactation disorder, infertility and sterility and helminthiasis (Sandabe et al., 2007; Bello et al., 2013). The target plant contains several bioactive chemical constituents. The most important bioactive constituents of 
494

this plant are alkaloids, tannins, flavonoids and phenolic compounds (Zaku et al., 2009). Ficus Sycomorus also has been shown to possess antioxidant, antibacterial, hypolipidemic, and hypoglycemic activities (Lansky et al., 2008; Ao et al., 2008; Abdel-Hameed, 2009). Phytochemical and toxicity evaluation on the stem bark of F. sycomorus L was carried out by Ibrahim et al. (2006) on mice with $\mathrm{LD} 50$ value of $471.1 \mathrm{mg} / \mathrm{kg}$. Its chemical constituents were found to include tannins, resins, steroid glycoside, reducing sugars and saponins. The extract is said to be moderately toxic to mice and therefore can be safely used ethno-medically at lower doses (Bello et al., 2015).

The aim of this work was to study the chemical composition of leaves and fruits of Ficus sycomorus L. and to study their effects as antioxidant, antimicrobial and anticancer activity. In addition, to determine the active compounds separated by GC-mass.

\section{Materials and Methods}

\section{Plant material}

Leaves and fruits of Ficus sycomorus L. (Moraceae) were collected from Faculty of Agriculture, Cairo University, Giza, Egypt. Ficus sycomorus was botanically characterized by Prof. Dr. Mohamed Osama from Plant taxonomy Department, Faculty of Agriculture, Cairo Univeristy, Egypt.

\section{Microbialstrain}

Table 1 illustrated the microorganisms which were used in this study and were obtained from the American Type Culture Collection (ATCC) as well as the culture collection of the Microbiology Lab, Cairo University Research Park (CURP), Faculty of Agriculture, Cairo University.

\section{Extraction method}

The fruits and leaves were cleaned and washed thoroughly under tap water, and then freeze-dried and grinded into fine powder using an electric blender. The powder was dried in an oven at $40{ }^{\circ} \mathrm{C}$ for $24 \mathrm{~h}$. The fine powder sample $(500 \mathrm{mg})$ was extracted in $10 \mathrm{ml}$ ethanol or distilled $\mathrm{H}_{2} \mathrm{O}$ for $24 \mathrm{~h}$ using a shaker, then the extract was filtered and the samples were stored at $4{ }^{\circ} \mathrm{C}$ till use (Sumathy and Sumathy, 2011). All analysis was done in the labs of Cairo University, Research Park (CURP), Cairo University, Faculty of Agriculture, Cairo, Egypt.

\section{Phytochemical composition of Ficus sycomorus}

The total phenolic content was estimated by Folin Ciocalteu method as described by Singleton and Rossi
(1965). The absorbance was measured at $765 \mathrm{~nm}$ using a spectrophotometer Thermo Scientific HERYIOS. Total phenolic content was expressed as $\mathrm{mg}$ gallic acid equivalent (GAE) per g dry weight. The flavonoids content was determined by aluminium trichloride method as described by Zhishen et al. (1999). The absorbance was determined at $510 \mathrm{~nm}$ using a spectrophotometer. Results expressed as $\mathrm{mg}$ Quercetin /g dry weight. Tannin content in fruits and leaves of Ficus sycomorus was determined by using FolinDenis reagent as described by Saxena et al. (2013). The absorbance was scan at $700 \mathrm{~nm}$ using spectrophotometer. Results expressed as mg Tannic acid /g dry weight. Alkaloids were measured according to the method described by Harborne (1998). The absorbance was taken at $565 \mathrm{~nm}$. The alkaloid concentration was calculated from the calibration curve of atropine used as standard and results expressed as g/100 g equivalent of atropine. The total anthocyanin contents were determined by the $\mathrm{pH}$ differential method (Lee et al., 2005) using a spectrophotometer (Thermo Scientific HERYIOS). The absorbance of the fruit extract was determined at 515 and $700 \mathrm{~nm}$ at $\mathrm{pH} 1.0$ and 4.5 buffers, respectively, using $\mathrm{A}=$ (A515 - A700) pH 1.0 - (A515 - A700) pH 4.5 with a molar extinction coefficient of 26,900. The results were expressed as mg of cyanidin-3-glucoside equivalent per 100 grams of fresh weight ( $\mathrm{g}$ cy-3-glu kg-1 FW).

\section{Lipid extraction}

The fruit and leaves of Ficus sycomorus oil content were determined using the Soxhlet extraction according to the official method (AOAC, 2000). Fifty g of dried fruits and leaves were ground and then extracted with petroleum ether in a Soxhlet apparatus for $6 \mathrm{~h}$. After extraction, the samples were ground again, but more finely, and extracted for $6 \mathrm{~h}$ (second extraction). Petroleum ether was vaporized under reduced pressure employing a rotavapor. Lipid content was expressed as g/100 g of fresh weight.

\section{Separation of fatty acids and unsaponifiables from lipid samples \\ Lipid material was saponified with methanolic $\mathrm{KOH}$} $(40 \%, \mathrm{w} / \mathrm{v})$ for $24 \mathrm{~h}$ at room temperature according to Ahmed et al. (1986). The unsaponifiables were extracted three times with ether. The aqueous layer was acidified with $\mathrm{HCl}(1: 1, \mathrm{v} / \mathrm{v})$ and the liberated fatty acids were extracted three times with ether. The combined extracts of unsaponifiables and fatty acids were washed many times with distilled water and then dried over anhydrous sodium sulfate. The standard and the sample fatty acids were converted to methyl esters using ethereal solution of diazomethane according to Vogel (1975).

Tablel. Microbial strains used to test the antimicrobial activities of Ficus sycamorus fruit and leaves extract

\begin{tabular}{|c|c|c|c|}
\hline Microbial group & Indicator strain & Positive control & Cultivation conditions \\
\hline \multirow{2}{*}{ Gram positive bacteria } & Staphylococcus aureus (ATCC 25923) & \multirow{2}{*}{ Kanamycin } & Muller-Hinton broth, $37^{\circ} \mathrm{C} / 24 \mathrm{~h}$ \\
\hline & Bacillus cereus (ATCC 33018) & & Muller-Hinton broth, $30^{\circ} \mathrm{C} / 24 \mathrm{~h}$ \\
\hline \multirow{2}{*}{ Gram negative bacteria } & Escherichia coli (ATCC 8739) & \multirow{2}{*}{ Polymyxin } & Muller-Hinton broth, $37^{\circ} \mathrm{C} / 24 \mathrm{~h}$ \\
\hline & Salmonella typhimureum (ATCC 14028) & & Muller-Hinton broth, $37^{\circ} \mathrm{C} / 24 \mathrm{~h}$ \\
\hline \multirow{2}{*}{ Fungus } & Aspergillus niger (nrrl 326) & \multirow{2}{*}{ Nystatin } & Sabouraud dextrose broth, $25^{\circ} \mathrm{C} / 3$ days \\
\hline & Candida albicans ATCC 10231 & & Sabouraud dextrose broth, $25^{\circ} \mathrm{C} / 24 \mathrm{~h}$ \\
\hline
\end{tabular}


Determination offatty acid composition by (GC-MS)

The methyl esters of fatty acid were measured by GCMS using Trace GC Model 2000 series created by Thermo equipped with Selective Detector Mass Spectroscopy Model SSQ 7000 created by Finnigan. This equipment was interfaced via HP chemstation version A 02.12 software (Hewelwett-Packard, Avondale, PA). The gas chromatography was equipped with DB-23 (J \& W 1222362) $25 \mu$ capillary column, $60 \mathrm{~m} \times 0.25 \mathrm{~mm}$ ID, and 0.15 $\mu \mathrm{m}$. The operational conditions for gas chromatography were as follows: injector temperature $250{ }^{\circ} \mathrm{C}$, carrier gas: helium at $30 \mathrm{~cm} / \mathrm{sec}$, measured at $150^{\circ} \mathrm{C}$, oven temperature $50{ }^{\circ} \mathrm{C}$ for $4 \mathrm{~min}, 150{ }^{\circ} \mathrm{C}$ for $4 \mathrm{~min}$ and held at $250^{\circ} \mathrm{C}$ until the chromatogram was completed. The detector temperature was $280{ }^{\circ} \mathrm{C}$. Mass spectroscopy operational parameters were electron ionization at $70 \mathrm{ev}$, accelerating voltage $10 \mathrm{kV}$ and scan $\mathrm{M} / \mathrm{Z}$ range from 50 to 500 , National Institute of Standards and Technology (NIST) library according to Jiang et al. (2006).

\section{Determination of sterols profile by $G C-M S$}

The unsaponifiable fractions were finally collected in ether and brought to condition beneath vacuum. The residue was analyzed using the gas chromatograph HP 5890 (Hewlett Packard) equipped with the MS detector (MSD 5970), EI, $70 \mathrm{ev}$ and fitted with a capillary column DB-1701 $(12 \mathrm{~m} \times 0.18 \mathrm{~mm} \times 0.4 \mathrm{~mm}$; J\&W Scientific). The column temperature was programmed from 260 to $300{ }^{\circ} \mathrm{C}$ whereas injection temperature was set at $280{ }^{\circ} \mathrm{C}$. Helium was the carrier gas at a rate of flow of $0.7 \mathrm{~cm}^{3} / \mathrm{min}$. Identification of peaks was supported the retention time of standard substances and MS spectra. Analyses were run in triplicate. Calculations of percent composition of demethylsterol fractions were based on the peak area.

\section{Extraction of phenolic and flavonoid compounds}

Dry sample $(0.2 \mathrm{~g})$ extracted with $20 \mathrm{ml}$ ethanol 80\%, soak in brawn bottle for $24 \mathrm{hr}$ at room temperature, centrifuged for $5 \mathrm{~min}$, volume adjusted to $25 \mathrm{ml}$ by ethanol $80 \%$, filtered through Whatman filter paper, $10 \mathrm{ml}$ of the solution evaporated to dryness then dissolved in $5 \mathrm{ml}$ HPLC grade methanol $50 \%$, filtered through PTFE filter with pore size $0.2 \mu \mathrm{m}$.

\section{Instrument condition for phenolic compounds}

Agilent 1260 infinity HPLC Series (Agilent, USA), equipped with Quaternary pump, a Zorbax Eclipse plusC18 column $100 \mathrm{~mm} \times 4.6 \mathrm{~mm}$ i.d., (Agilent technologies, USA), operated at $30^{\circ} \mathrm{C}$. The separation is achieved using a ternary linear elution gradient with (A) HPLC grade water $0.2 \% \mathrm{H}_{3} \mathrm{PO}_{4}(\mathrm{v} / \mathrm{v}),(\mathrm{B})$ methanol and (C) acetonitrile. The injected volume was $20 \mu$ l. Detection: VWD detector set at $284 \mathrm{~nm}$.

\section{Instrument condition for flavonoids}

HPLC, Smart line, Knauer, Germany., equipped with binary pump, a Zorbax Eclipse plusC18 column $150 \mathrm{~mm} x$ $4.6 \mathrm{~mm}$ i.d. (Agilent Technologies, USA), operated at 35 ${ }^{\circ} \mathrm{C}$. Eluent: methanol: $\mathrm{H}_{2} \mathrm{O}$ with $0.5 \% \mathrm{H}_{3} \mathrm{PO}_{4}, 50: 50$ with flow rate $0.7 \mathrm{ml} / \mathrm{min}$, the injected volume was $20 \mu \mathrm{l}$. Detection: UV detector set at $273 \mathrm{~nm}$ and data integration by claritychrom ${ }^{@}$ software. This method was the modified of methods Goupy et al. (1999) and Mattila et al. (2000) for fractionate the polyphenols and flavonoids, respectively.

\section{$D P P H$ free radical scavenging activity (RSA)}

The antioxidant activity of fruits and leaves of Ficus sycomorus extract was measured in terms of hydrogen donating or radical-scavenging ability using the stable DPPH method as modified by Hae-Ryong et al. (2006). The reaction mixture containing $1 \mathrm{ml}$ of the extract at different concentrations $(40,80,120,150 \mu \mathrm{g} / \mathrm{ml})$ and $1 \mathrm{ml}$ of DPPH $(0.2 \mathrm{mM})$ was vigorously shaken and incubated in darkness at room temperature for 30 minutes. The absorbance was browse at $517 \mathrm{~nm}$ exploitation UV-visible photometer. Radical scavenging activity was expressed as percent of inhibition and was calculated exploitation the subsequent formula:

$\% \mathrm{DPPH}=[$ Absorbance of Control - Absorbance of Sample / Absorbance of Control] $\times 100$

\section{Determination of reducing power}

The ability of the tested extracts to reduce $\mathrm{Fe}^{3+}$ was assayed by the method of Chou et al. (2009). The absorbance was measured at $700 \mathrm{~nm}$. The results were expressed as $\mu \mathrm{g}$ of gallic acid equivalent per $100 \mathrm{~g} \mathrm{DW}$.

\section{Antibacterial activity}

Agar disc diffusion method was used to evaluate the antibacterial activity of fruit and leaves of Ficus sycomorus as describe by Bauer et al. (1966). The strains were grownup on Mueller-Hinton agar slants at $37{ }^{\circ} \mathrm{C}$ for $24 \mathrm{~h}$ and checked for purity. After the incubation, the cells were washed off the surface of agar and suspended in sterile physiological solution. The number of cells in $1 \mathrm{ml}$ of suspension for inoculation measured by McFarland nefelometer was $5 \times 107 \mathrm{CFU} / \mathrm{ml}$. $1 \mathrm{ml}$ of those suspensions was homogenized with $9 \mathrm{ml}$ of liquified $\left(45^{\circ} \mathrm{C}\right)$ Mueller-Hinton agar and poured into Petri dishes. On the surface of the agar, $5 \mathrm{~mm}$ diameter paper discs (HiMedia, Mumbai, India) were applied and impregnated with $15 \mu \mathrm{l}$ of samples. The plates were incubated at the optimum temperature for every indicator strain (Table 1) and tested when 24, 48 and $72 \mathrm{~h}$. Growth inhibition was scored positive within the presence of a detectable clear zone (ZI) round the disc and expressed in $\mathrm{mm}$. Experiments were carried out in triplicates and the inhibition zone was recorded as the average of the replicates \pm SD.

\section{In vitro cytotoxicity assay}

Liver cell line (HepG2), colorectal adenocarcinoma (Caco-2) and Breast cell line (MCF-7) were purchased from CURP, faculty of Agriculture at Cairo University (Egypt). Cells were maintained in (DMEM) supplemented with $10 \%$ heat-inactivated fetal bovine serum, $100 \mathrm{\mu g} / \mathrm{ml}$ streptomycin and 100 units $/ \mathrm{ml}$ penicillin g potassium, in a humidified $90 \%$ and $5 \%(\mathrm{~V} / \mathrm{V}) \mathrm{CO}_{2}$ atmosphere at $37{ }^{\circ} \mathrm{C}$. The cytotoxicity of ethanolic extracts was tested by the neutral red (NR) assay as previously described by Repetto $e t$ al. (2008). Exponentially growing cells were collected using $0.25 \%$ Trypsin-EDTA and seeded in 96- well plates at 
496

20000 cells/well. After incubation (overnight), extracts were added in various concentrations $(10,50,100,200,400$, and $800 \mu \mathrm{g} / \mathrm{ml}) ; 4$ wells for each concentration. After treatment with extracts for $24 \mathrm{~h}$, media were removed and cells were exposed to neutral red solution for 4 hours at 37 ${ }^{\circ} \mathrm{C}$. Destin solution was used to dissolve the NR stained cells and color intensity was measured at $540 \mathrm{~nm}$ microplate reader (Biotek, ELX808).

The fruits and leaves of Ficus sycomorus extraction for $G C / M S$ analysis

The fruits and leaves were cleaned, shade dried and pulverized to a powder in a mechanical grinder. Required amount of powder was weighed and transferred to dramatist flask and treated with methanol till the powder is absolutely immersed. The flask was jolted each hour for the primary 6 hours and so it had been unbroken aside and once more jolted after 24 hours. This method was recurrent for 3 days and so the extract was filtered. The extract was collected and evaporated to dryness by using a vacuum distillation unit. The final residue obtained was then subjected to GC-MS analysis.

$G C-M S$ analysis

GC-MS analysis of these extracts was performed using an Agilent 7000 Series Triple, Quad Gas Chromatograph interfaced to a Mass Spectrometer (GC/MS/) equipped With a Elite-5MS (5\% diphenyl/ 95\% dimethyl poly siloxane $)$ fused a capillary column $(30 \times 0.25 \mu \mathrm{m}$ ID $\times$ $0.25 \mu \mathrm{m} \mathrm{df}$ )) For GC-MS detection an electron Ionization system with ionizing energy of $70 \mathrm{ev}$ was used. Helium gas (99.999\%) was used as the carrier gas at a constant flow rate $1 \mathrm{ml} / \mathrm{min}$ and injection volume of $2 \mu \mathrm{l}$ was employed (split ratio of 10:1); injector temperature $250{ }^{\circ} \mathrm{C}$; ion-source temperature $200{ }^{\circ} \mathrm{C}$. The oven temperature programmed from $110^{\circ} \mathrm{C}$ (iso thermal for $2 \mathrm{~min}$ ) With an increase of 10 ${ }^{\circ} \mathrm{C} / \mathrm{min}$ to $200{ }^{\circ} \mathrm{C}$, then $5^{\circ} \mathrm{C} / \mathrm{min}$ to $280{ }^{\circ} \mathrm{C}$, ending with a $9 \mathrm{~min}$ iso thermal at $280{ }^{\circ} \mathrm{C}$, mass spectra were taken at $70 \mathrm{ev}$ : a scan interval of 0.5 second and fragments from 45 to 450Da, total GC Running time was 36 minutes. The relative \% amount of each component was calculated by comparison its average Peak area to the total areas. Software adopted to handle mass spectra and chromatograms was Turbomass.

Interpretation of mass spectrum GC-MS was conducted using the database of Nationl Institue of Standard and Technology (NIST) having more than 62,000 patterns. The spectrum of the unknown components stored in the NIST library. The name, molecular weight and structure of the components of the test materials were ascertained (Bagavathi and Ramasamy, 2012).

\section{Statistical analysis}

All results were expressed as mean values \pm standard deviation. Comparisons were performed by analysis of variance (ANOVA). Statistical analyses were run using SAS software.

\section{Results and Discussion}

Phytochemical compounds of fruits and leaves of Ficus sycomorus

The phytochemical compounds of the two extracts of fruits and leaves of Ficus sycomorus are presented in Table 2.
The ethanolic and ethyl acetate extracts of leaves of Ficus sycomorus have higher concentrations of total phenols, flavonoids, tannins, alkaloids and anthocyanin than the fruit extracts. The ethanolic extract in both fruits and leaves of Ficus sycomorus gave higher concentrations of phytochemical compounds than the ethyl acetate extract. These results are in accordance with Mudi et al. (2015) who found that the phytochemical analysis of of Ficus sycomorus revealed the presence of alkaloids, tannins, saponins, flavanoids and steroids in both the aqueous extracts of the leaves and the fruits. These classes of compounds are known to be biologically active and are associated with the antimicrobial activities of Ficus sycomorus (Kesba and ElBeltagi, 2012; Mohamed et al., 2013; El-Beltagi et al., 2018). Alkaloids have been associated with medicinal applications in plants, among which is their toxicity against cells of foreign organisms. These bioactivities have been widely studied for their potential use in the inhibitory activities of human cancer cell lines (Nobori et al., 1994; Akinpelu et al., 2008). Alkaloids inhibit certain mammalian enzymatic activities like those of phosphodiesterase, prolonging the action of CAMP. They additionally have an effect on glucagons and thyroid stimulating hormones, while some forms of alkaloids which extracted from Rhazya stricta have been reported to be carcinogenic (Soonham, 2015). However, some alkaloids are used either as an analgesic, antispasmodic or bactericidal agents (Tim-Cushnie, 2014). Plant phenolic compounds, especially flavonoids are currently of growing interest owing to their supposed properties in promoting health (antioxidants) and antimicrobial activity (Rauha et al., 2000; Abd El- Rahman et al., 2012). Flavonoids also exhibit a wide range of biological activities such as antimicrobial, antiinflammatory, analgesic and cystostatic, hypoglycemic and antioxidant properties (Scalbert, 1991; Hodek et al., 2002; Abdel-Rahim and El-Beltagi, 2010). The broad therapeutic effects of flavonoids will be mostly attributed to their antioxidant properties. In addition to an antioxidant effect, flavonoid compounds may exert protection against heart disease through the inhibition of cyclooxygenase and lipoxygenase activities in platelets and macrophages (Mark, 1998; Shallan et al., 2010). Tannins are reported to inhibit the growth of microorganisms by precipitating microbial proteins and making nutritional proteins unavailable for them; they form irreversible complexes with proline rich proteins, resulting in the inhibition of the cell protein synthesis. They have important roles such as stable and potent antioxidants (Ogunleye and Ibitoye, 2003; Kobeasy et al., 2011). Plant tannin has been recognized for their pharmacological properties and is thought to form trees and shrubs a difficult meal for several caterpillars (Aiyelaagbe and Osamudiamen, 2009).

\section{Fatty acid and sterols compounds of fruits and leaves of} Ficus sycomorus

The ethanolic extract of fruits and leaves of Ficus sycomorus contains 10 fatty acid compounds, 7 compounds saturated fatty acids and 3 compounds unsaturated fatty acids (Table 3). The main constituent is C18:2 linoleic acid followed by C18:1 oleic acid and C18:3 linolenic acid. Leaves extract contains high amount of saturated fatty acids $(27.28 \%)$ than fruit extract which contain $26.58 \%$. On the other hand, fruit extract contains high amount of 
unsaturated fatty acids (73.42) than leaves extract which contain (72.72\%). These results are in accordance with Ivanov et al. (2018) who found that the highest value of polyunsaturated fatty acid $\alpha$-linolenic acid C18:3 and linoleic acid C18:2 were established in all extracts of fig (Ficus carica L.) leaves. It is well known that polyunsaturated fatty acids can influence some physical properties of the cellular membranes such as fluidity and permeability (Ward and Singh, 2005). Moreover, the benefits of polyunsaturated fatty acids in some diseases, such as cardiovascular diseases and autoimmune disorders, have been reported (Reiffel and McDonald, 2006; Afify et al., 2018). Results clearly showed that the fruits and leaves extract of Ficus sycomorus contained more unsaturated fatty acids as $\alpha$-linolenic acid and linoleic acid. These natural components have been used as co-emulsifiers, emollients and thickeners in cosmetics and food industry (Pejin et al., 2014). Also, oleic acid ester is known to have potent antibacterial and antifungal (Seidel and Taylor, 2004). Oleic acid in concentrations as low as $0.7 \%(\mathrm{v} / \mathrm{v})$ has been found to be fungistatic against a wide of molds and yeasts (Sheba $e t$ al., 1999).

Phytosterols inhibit the absorption of intestinal and endogenous biliary cholesterol. Plants contain free and esterified phytosterols which will be acylated with $\beta$ sitosterol, campisterol and stigmaserol. These phytochemical compounds play important role in cellular processes such as regulation of membrane fluidity, adaptation of membranes to temperature, participation in cellular differentiation and proliferation (MacKay and Jones, 2011).

The results in Table 3 showed that the ethanolic extract of fruits and leaves of Ficus sycomorus contain five compounds of sterols sperated by HPLC. The most constituent is $\beta$-Sitosterol followed by Stigmasterol and Campesterol. Leaves extract contain high amounts of $\beta$ Sitosterol and Campesterol than fruits extact. These results are in accordance with Ivanov et al. (2018), who found that $\beta$-sitosterol given the most phytosterol within the fig leaves. This compound could be a non-competitive inhibitor of 5 $\alpha$-reductase and it possesses proved anti-inflammatory drug impact thanks to inhibition of 5-lipoxygenase pathways of arachidonic acid (Cabeza et al., 2003; Prieto et al., 2006).

Plant steroids are renowned to be necessary for their cardiotonic, insecticidal and anti-microbial properties. They are conjointly utilized in nutrition, herbal medicines, cosmetics and they are habitually utilized in drugs due to their profound biological activities (Denwick, 2002). Steroids present in plants are cardiotonic in nature and are reported to have antidiabetic and anti-fungal properties (Kamel, 1991). They are stocked in plant cells as inactive precursors but are readily converted into biological active antibiotics by enzymes in response to microorganism attack.

Table 2. Quantitative phytochemical analysis of Ficus sycamorus fruit and leaves extracts

\begin{tabular}{|c|c|c|c|c|}
\hline \multirow{2}{*}{ Constituents } & \multicolumn{2}{|c|}{ Fruits extracts } & \multicolumn{2}{|c|}{ Leaves extracts } \\
\hline & Ethanolic & Ethyl acetate & Ethanolic & Ethyl acetate \\
\hline $\begin{array}{c}\text { Total phenolic } \\
\text { (mg Gallic acid } / \mathrm{g} \mathrm{DW})\end{array}$ & $51.88 \pm 2.04^{a}$ & $33.55 \pm 1.38^{\mathrm{b}}$ & $63.54 \pm 0.53^{\mathrm{a}}$ & $44.22 \pm 0.94^{\mathrm{b}}$ \\
\hline $\begin{array}{c}\text { Total flavonoid } \\
\text { (mg Quercetin /g DW) }\end{array}$ & $8.57 \pm 1.01^{a}$ & $2.48 \pm 0.16^{\mathrm{b}}$ & $12.58 \pm 0.01^{\mathrm{a}}$ & $5.58 \pm 0.06^{\mathrm{b}}$ \\
\hline $\begin{array}{c}\text { Total tannin } \\
(\mathrm{mg} \text { Tannic acid } / \mathrm{g} \mathrm{DW})\end{array}$ & $7.11 \pm 0.22^{a}$ & $4.92 \pm 0.28^{b}$ & $11.11 \pm 0.23^{\mathrm{a}}$ & $6.14 \pm 0.09^{b}$ \\
\hline $\begin{array}{l}\text { Total alkaloid } \\
(\mathrm{g} / 100 \mathrm{~g} \mathrm{DW})\end{array}$ & $4.03 \pm 0.43^{\mathrm{a}}$ & $3.07 \pm 0.13^{b}$ & $8.42 \pm 0.34^{\mathrm{a}}$ & $5.57 \pm 0.18^{\mathrm{b}}$ \\
\hline $\begin{array}{c}\text { Total anthocyanin } \\
\text { (mg cy-3-glu /100g FW) }\end{array}$ & $113.44 \pm 0.84^{\mathrm{a}}$ & $86.17 \pm 0.55^{b}$ & $142.51 \pm 0.43^{\mathrm{a}}$ & $113.66 \pm 0.36^{b}$ \\
\hline
\end{tabular}

Table 3. Fatty acids and sterols compositions percent of Ficus sycamorus oils

\begin{tabular}{|c|c|c|c|}
\hline Lipid Composition & Constituents & Ethanolic extract of fruits & Ethanolic extract of leaves \\
\hline \multirow{13}{*}{ Fatty acids } & C12:0 Lauric acid ${ }^{2}$ & 0.31 & 0.22 \\
\hline & C14:0 Myristic acid ${ }^{2}$ & 3.61 & 3.33 \\
\hline & C16:0 Palmitic acid & 10.12 & 10.59 \\
\hline & C18:0 Stearic acid ${ }^{a}$ & 11.50 & 12.46 \\
\hline & C18:1 Oleic acid & 24.06 & 27.32 \\
\hline & C18:2 Linoleic acid & 30.03 & 29.82 \\
\hline & C18:3 Linolenic acid & 19.34 & 15.58 \\
\hline & C20:0 Arachidic acid ${ }^{a}$ & 0.27 & 0.062 \\
\hline & C22:0 Behenic acid ${ }^{a}$ & 0.19 & 0.092 \\
\hline & C24:0 Lignoceric acid ${ }^{2}$ & 0.59 & 0.53 \\
\hline & ${ }^{a}$ SFA & 26.58 & 27.28 \\
\hline & 'USFA & 73.42 & 72.72 \\
\hline & USFA/SFA & 2.76 & 2.67 \\
\hline \multirow{5}{*}{ Sterols } & Campesterol & 10.15 & 11.88 \\
\hline & Stigmasterol & 15.62 & 10.39 \\
\hline & Lanosterol & 2.73 & 1.86 \\
\hline & $\beta$-Sitosterol & 70.66 & 75.61 \\
\hline & $\Delta^{5}$-Avenasterol & 0.84 & 0.26 \\
\hline
\end{tabular}


498

Phenolic and flavonoid compounds of fruits and leaves of Ficus sycomorus

Medicinal plants have a large sort of phenolic compounds, like flavonoids that act potentially as antioxidants, scavenging free radicals, reactive oxygen species and inhibit lipid peroxidation (Kumawat et al., 2012).

The ethanolic extract of fruits and leaves of Ficus sycomorus contains 18 phenolic compounds (Table 4). The most constituent in fruits extract is Benzoic acid followed by Vanillic acid and Caffeine. Additionally, the most constituent in leaves extract is Ellagic acid followed by Rutin and Chlorgenic acid. Also, Pyrogallol, $p$-Hydroxy benzoic acid and Chlorgenic acid found only in leaves extract. While, Quinol and o- Coumaric acid found only in fruits extract. Similar results are reported by El-Sayed et al. (2010) who found that Gallic acid, quercetin, rutin, $\beta$-Sitosterol glucopyranoside, isoquercitrin and quercetin galactopyranosyl $(1 \rightarrow 6)$ glucopyranoside are the compounds that isolated from the leaves of Ficus sycomorus.

In addition, the ethanolic extract of fruits and leaves of Ficus sycomorus contains 6 flavonoids compounds like Myricetin, Cinnamic acid, Quercitin, Rosmarinic acid, Neringenin and kaempferol. While, Quercitin found only in fruit extract. Blasiak et al. (2002) found that Quercetin, beside the vitamin $\mathrm{C}$, might play a crucial role within the protection of DNA molecules from harm and therefore stop the appearance of mutations and cancer. Quercitrin and Rutin is a quercetin 3-glucosid with significant antioxidative and antibacterial effects (Arima et al., 2002).

Fruit extract contains high amounts of Kaempferol than leaves extract. Also, high amounts of Myricetin and Neringenin found in leaves extract than fruit extract. Rauha et al. (2000) found that kaempferol and its derivatives have antibacterial activity.

Antioxidant activity of fruits and leaves of Ficus sycomorus

Antioxidants are substances that defend living cells from the harm caused by unstable molecules known as free radicals. Antioxidants are renowned to act and stabilize free radicals, thereby preventing harm. The free radical damage might result in the development of cancer (Prior et al., 2005). Antioxidant molecules are capable of retarding or preventing the oxidation of other molecules. Oxidation refers to the chemical reaction that transfers electrons from one substance to another. Oxidation reactions produce free radicals that begin chain reactions that harm the cells. Antioxidants terminate these chain reactions by removing free radical intermediates and inhibiting other oxidation reactions. Examples of some antioxidants are Beta-carotene, lycopene, vitamins A, C and E (Lopez et al., 2007).

The ethanolic extract of each fruits and leaves of Ficus sycomorus gave the high antioxidant activity as compared with ethyl acetate extract and also the leaves extract which gave the hight pronounced activity than fruit extract. The scavenging of DPPH radicals inflated with increasing extract concentration from 40,80, 120 and $150 \mu \mathrm{g} / \mathrm{ml}$ (Table 5). The $\mathrm{IC}_{50}$ value of ethanolic and ethyl acetate extracts of leaves was below than fruits extract. IC $\mathrm{C}_{50}$ values indicate the concentration of the test sample needed to inhibit $50 \%$ of the free radicals. The $\mathrm{IC}_{50}$ value could be a parameter widely applied to measure the free radical scavenging activity (Cuvelier et al., 1992); a smaller $\mathrm{IC}_{50}$ value corresponds to a higher antioxidant activity.

The reducing power capacity reflects the presence of an antioxidant for the reduction of ferricyanide ions $[\mathrm{Fe}(\mathrm{CN})$ $6]^{3-}$ to ferrocyanide ions $[\mathrm{Fe}(\mathrm{CN}) 6]^{4}$. This reducing property is mostly related to the presence of a reducer exercising an antioxidant action by breaking the free radical chains; yielding a hydrogen atom (Gordon, 1990). The ethanolic extract of each fruits and leaves of Ficus sycomorus gave higher reducing power activity than ethyl acetate extract and the leaves extract gave higher reducing power activity than fruit extract (Table 5).

Antioxidant activities of stem bark extracts of $F$. sycomorus using DPPH radical scavenging activity, hydrogen peroxide scavenging activity and ferric reducing antioxidant power showed that the extracts significantly $(p<0.05)$ exhibited robust antioxidant activity compared to the standard (L-Ascorbic Acid) at the concentrations used (Daniel and Dluya, 2016). The antioxidant activity of the extracts may be associated with the high content of phenolics, tannins and flavonoids. The effects of the extracts could be due to the biological systems that are connected to their ability to transfer electrons to free radicals, chelate metals, activate antioxidant enzymes, reducing radicals of alpha-tocopherol or to inhibit oxidases (Bruneton, 2009).

The free radicals that are concerned within the process of lipid peroxidation are considered to play a serious role in varied chronic pathologies such as cancer and cardiovascular diseases among others. Therefore, the ability of the plant extracts as free radical scavenger disclosed that these extracts may use as new of natural antioxidants and prevent the reactive radical species from reacting biomolecules such as lipoproteins, polyunsaturated fatty acid (PUFA), DNA, amino acids, proteins and sugars in susceptible biological and food systems (Chew et al., 2008; El-Beltagi, 2011).

\section{Antimicrobial activity of fruits and leaves of Ficus sycomorus}

The antimicrobial activity of fruits and leaves of Ficus sycomorus extracts varied according to the species of bacteria and fungi tested and the solvents used (Table 6). The data indicated that the ethanolic extract of fruits and leaves of Ficus sycomorus exhibited the highest antimicrobial activity against the investigated food pathogens as compared with the ethyl acetate extract. In addition, leaves extract produced potent antimicrobial activity as compared to fruit extract.

All extracts of fruits and leaves of Ficus sycomorus showed higher antibacterial activity (the diameter of zone of inhibition increased) against gram negative bacteria (Escherichia coli and Salmonella typhimureum) than gram positive bacteria (Staphylococcus aureus and Bacillus cereus). Also, ethanolic and ethyl acetate extract gave higher antifungal activity against Candida albicans than Aspergillus niger. Similar results are reported by Manimozhi et al. (2012) who found that the acetone, methanol and ethyl acetate of Ficus spp. showed good antibacterial activity against $P$. aeruginosa, E. coli, $P$. vulgaris, $B$. subtilis, and $S$. aureus pathogens.Also, Al-matani et al. (2015) reported that the antimicrobial activity of the crude fruit extracts of 
Ficus sycomorus showed strong activity against four Grampositive and Gram-negative bacterial strains, $S$. aureus, $E$. coli, Haemophilus influenza and Proteus spp. In addition, the fruit extract of Ficus sycomorus showed area of inhibition in the test organisms; $E$. coli, $K$. pneumoniae, $S$. aureus, $P$. aeruginosa and P. vulgaris (Braide el al., 2018).

The antibacterial activity exhibited could be due to the presence of phytochemicals (flavonoids, saponins, terpendois, phenol and tannins) and the occurrence of phenolic compounds in the extract (Ramde-Tiendrebeogo et al., 2012).

\section{Anticancer activity of fruits and leaves of Ficus sycomorus}

Data in Table 7 showed the cytotoxic activity of Ficus sycomorus as an anticancer agent. The percentage of Liver cell line (HepG2), Colorectal adenocarcinoma (Caco-2) and Breast cell line (MCF-7) viability was decreased with increasing the concentrations of the ethanolic extract of fruits and leaves of Ficus sycomorus (500, 1000, 1500, 2000, $3000 \mu \mathrm{g} / \mathrm{ml}$ ). The most pronounced reduction in the viability of cancer cells was detected after treatment with fruit extract than leaves extract. The high concentrations of ethanolic extract of fruits caused the high reduction in the viability of cancer cells, especially in colorectal adenocarcinoma (Caco-2) cell line. Cancers commonly related to enhanced risk of death and also the noxious facet effects caused by the modern medicine. These results are in accordance with Mousa et al. (1994) who showed that the fruit extracts of $F$. benjamina, $F$. bengalensis, $F$. religiosa and Ficus sycomorus exhibited antitumor activity in the potato disc bioassay. Also, the natural and compounds synthesised from Ficus carica showed in vitro inhibitory effects on proliferation of various cancer cell lines (Joseph and Raj, 2011).

The anticancer effect of ethanolic extract may be due to the presence of poly phenols that play an important role in antioxidant activity (Wu et al., 2004) and have evidently shown antiproliferative activity or cytotoxicity to human oral cancer cells (Seeram et al., 2004), melanoma cells (Rodriguez et al., 2002) and lung metastasis induced by B16F10 melanoma cells (Menon et al., 1995). Also, the ethanolic extract contains gallic acid also exerts a cytotoxic activity against tumoral cells from leukemia, lung and prostate cancer origins (You and Park, 2010). In addition, sterols were found to inhibit tumor promotion in two-stage carcinogenesis in mice (Okwu, 2001). Steroid compounds are well known for their anticancer activity by inhibition of cancer cell proliferation, angiogenesis and induction of apoptosis (Kazlowska et al., 2013).

Table 4. HPLC analysis of phenolic and flavonoid compounds of Ficus sycamorus fruits and leaves extracts

\begin{tabular}{|c|c|c|}
\hline \multirow{2}{*}{ Compounds } & \multicolumn{2}{|c|}{ Conc. $\mu \mathrm{g} / \mathrm{mg}$ DW } \\
\hline & Ethanolic extract of fruits & Ethanolic extract of leaves \\
\hline Pyrogallol & - & 1.97 \\
\hline Quinol & 2.82 & - \\
\hline Gallic acid & 1.72 & 4.72 \\
\hline Catechol & 2.66 & 73.59 \\
\hline p-Hydroxy benzoic acid & - & 45.38 \\
\hline Caffeine & 11.87 & 4.61 \\
\hline Chlorgenic acid & - & 272.94 \\
\hline Vanillic acid & 23.02 & 41.44 \\
\hline Syringic acid & 6.77 & 3.82 \\
\hline Caffeic acid & 3.36 & 10.03 \\
\hline Vanillin & 4.42 & 13.17 \\
\hline$p$-Coumaric acid & 5.23 & 82.44 \\
\hline Ferulic acid & 1.86 & 1.04 \\
\hline Benzoic acid & 73.21 & 45.87 \\
\hline Rutin & 1.33 & 366.89 \\
\hline Ellagic acid & - & 3303.04 \\
\hline o- Coumaric acid & 2.90 & - \\
\hline Salicylic acid & 5.57 & 106.37 \\
\hline \multicolumn{3}{|l|}{ Flavonoids compounds } \\
\hline Myricetin & 20.31 & 141.24 \\
\hline Cinnamic acid & 1.17 & 49.96 \\
\hline Quercitin & 11.25 & - \\
\hline Neringenin & 22.13 & 70.83 \\
\hline Rosmarinic acid & 15.31 & 24.02 \\
\hline Kaempferol & 108.72 & 20.40 \\
\hline
\end{tabular}


Table 5. Antioxidant activity of Ficus sycamorus fruit and leaves extracts against DPPH method and reducing power methods

\begin{tabular}{ccccc}
\hline \multirow{2}{*}{ Conc. $(\mu \mathrm{g} / \mathrm{ml})$} & \multicolumn{2}{c}{ Fruits } & \multicolumn{2}{c}{ Leaves } \\
\cline { 2 - 5 } & DPPH \% in ethanolic extract & $\begin{array}{c}\text { DPPH \% in ethyl acetate } \\
\text { extract }\end{array}$ & $\begin{array}{c}\text { DPPH \% in ethanolic } \\
\text { extract }\end{array}$ & $\begin{array}{c}\text { DPPH \% in ethyl acetate } \\
\text { extract }\end{array}$ \\
\hline 40 & 55.003 & 53.117 & 58.426 & 55.235 \\
80 & 59.232 & 53.543 & 63.541 & 56.426 \\
120 & 65.763 & 55.994 & 67.426 & 59.475 \\
150 & 72.471 & 56.526 & 75.249 & 63.174 \\
ICso $(\mu \mathrm{g} / \mathrm{ml})$ & 20.312 & 37.652 & 18.443 & 33.348 \\
Reducing power activity $(\mu \mathrm{g}$ & $15.58 \pm 0.44$ & $10.42 \pm 0.20$ & $22.53 \pm 0.37$ & $16.19 \pm 0.18$ \\
Gallic acid $/ 100 \mathrm{~g} \mathrm{DW}$ & & & & \\
\hline
\end{tabular}

Table 6. Antibacterial activities of Ficus sycamorus fruit and leaves extracts against selected bacterial strains and fungus

\begin{tabular}{|c|c|c|c|c|c|c|}
\hline \multirow{3}{*}{ Samples } & \multicolumn{6}{|c|}{ Inhibition zone $(\mathrm{mm})^{*}$} \\
\hline & \multicolumn{2}{|c|}{ Gram positive bacteria } & \multicolumn{2}{|c|}{ Gram negative bacteria } & \multicolumn{2}{|c|}{ Fungus } \\
\hline & S. aureus & B. cereus & E. coli & S. typhimureum & A. niger & C. albicans \\
\hline Fruits ethanolic extract & $8.18 \pm 0.22$ & $9.25 \pm 0.16$ & $15.37 \pm 0.36$ & $17.11 \pm 0.25$ & $9.71 \pm 0.19$ & $10.32 \pm 0.42$ \\
\hline Fruits ethyl acetate extract & $6.14 \pm 0.44$ & $8.14 \pm 0.35$ & $12.72 \pm 0.24$ & $14.31 \pm 0.17$ & $6.43 \pm 0.18$ & $8.75 \pm 0.33$ \\
\hline Leaves ethanolic extract & $10.46 \pm 0.42$ & $12.61 \pm 0.29$ & $17.82 \pm 0.51$ & $19.31 \pm 0.11$ & $12.60 \pm 0.33$ & $13.21 \pm 0.16$ \\
\hline Leaves ethyl acetate extract & $8.11 \pm 0.13$ & $10.41 \pm 0.15$ & $14.09 \pm 0.16$ & $15.21 \pm 0.52$ & $7.32 \pm 0.26$ & $9.34 \pm 0.41$ \\
\hline
\end{tabular}

Table 7. Anticancer activities of the ethanolic extract of fruits and leaves of Ficus sycamores

\begin{tabular}{|c|c|c|c|c|c|c|}
\hline \multirow{2}{*}{$\begin{array}{l}\text { Concentrations } \\
\qquad(\mu \mathrm{g} / \mathrm{ml})\end{array}$} & \multicolumn{2}{|c|}{$\begin{array}{c}\text { Liver cell line } \\
\text { (HepG2) Viability \% }\end{array}$} & \multicolumn{2}{|c|}{$\begin{array}{l}\text { Colorectal adenocarcinoma } \\
\text { (Caco-2) cell line Viability \% }\end{array}$} & \multicolumn{2}{|c|}{$\begin{array}{c}\text { Breast cell line } \\
(\text { MCF-7) Viability \% }\end{array}$} \\
\hline & Fruits & Leaves & Fruits & Leaves & Fruits & Leaves \\
\hline 500 & 100 & 100 & 100 & 100 & 100 & 100 \\
\hline 1000 & 94 & 97 & 99 & 99 & 93 & 91 \\
\hline 1500 & 86 & 89 & 71 & 93 & 91 & 88 \\
\hline 2000 & 79 & 82 & 68 & 88 & 85 & 78 \\
\hline 3000 & 74 & 78 & 62 & 81 & 76 & 71 \\
\hline $\mathrm{IC}_{50}(\mu \mathrm{g} / \mathrm{ml})$ & 410 & 750 & 416 & 860 & 290 & 219 \\
\hline
\end{tabular}

$G C$ - mass analysis of fruits and leaves of Ficus sycomorus

Twilve compounds were identified in the ethanolic extract of fruits of Ficus sycomorus by GC-MS analysis. The active principles with their retention time (RT) molecular formula, molecular weight and $\%$ of peak area are present in Table (8) and Fig. (1). The prevailing compounds were Ambrosiol (8,9-dihydroxy-6,9a-dimethyl-3-methylidenedecahydro-azuleno[4,5-b]furan-2(3h)-one), N-Methyl-2chloropyrrole, 4-Amino-3,5-di-2-pyridyl-4H-1,2,4-triazole, 2-Methylpyrrole-3-carbonitrile, 1,4-Cyclohexanedione, 2Isopropyl-1,3-dioxolane, Phenyltrihydrosilane, Ethanone, 1-(2-methyl-1-cyclopenten-1-yl), Methyl ester of gibberellin A5, Benzene, 1,4-dimethyl-2,5-bis(1-methylethyl), 2,4-Ditert-butylphenol and Phenyl 4-[bis(ethoxycarbonyl)but-3ynyl]-2,3,4-trideoxy-.alpha.,L-glcero-pent-2-.

In addition, 29 compounds were identified in the ethanolic extract of Ficus sycomorus leaves by GC-MS analysis Table (9) and Fig. (2). The prevailing compounds were Gamma-Undecalactone, 2-Ethylcyclohexyl 3chloropropanoate, 2-Ethylcyclohexyl bromoacetate, Aspidocarpine, 5-(1-Hydroxy-2-propanyl)-2methylcyclohexanol, 2,7-Anhydro-l-galactoheptulofuranose, 1,5-Naphthalenediol, Thiosulfuric Acid, Quinic acid, $\alpha$-D-Glucopyranoside de $\alpha$-D-glucopyranosyl(1->3)- $\beta$-D-fructofuranosyle, hydrate, O-Benzyl-L-serine,
4-Allyl-2,6-dimethoxyphenol,

[1,1'-Bicyclopropyl]-2octanoic acid, 2'-hexyl-, methyl ester, D-chiro-Inositol, 3-O(2-amino-4-(carboxyiminomethyl)amino)-2,3,4,6tetradeoxy-, Neo Inositols, Psoralene, Phytol, acetate, 6-(3Hydroxy-but-1-enyl)-1,5,5-trimethyl-7-

oxabicyclo[4.1.0]heptan-2-ol, Methyl Palmitate, Palmitic Acid, Methyl (11E,14E)-octadeca-11,14-dienoate, Methyl Linolenate, Phytol, Methyl isostearate, Linoleoyl chloride, cis-5,8,11,14,17-Eicosapentaenoic acid, Quercetin 7,3',4'Trimethoxy and Lupeol. Similar results are reported by Romeh (2013) who found that the chemical analysis of vaporous from $F$. sycomorus leaves allowed identification of 1, 2 benzenedicarboxilic acid, diisooctyl ester (45.06\%), nHexadecanoic acid (7.67\%), 1H-pyrazole,4-Nitro (5.13\%), 3-Hexen-1- ol, benzoate, Z (4.57\%), oleic acid (4.30\%), hexanedioic acid, bis (2-ethyl hexyl) ester (4.15\%), methyl oleate (2.41\%), 3- buten- 2-one, 4-(2, 6, 6- trimethyl-1cyclohexen-1-yl) (2.08\%), 9- octadecenoic acid (Z)- 2hydroxy-1-(hydroxymethyl) ethyl ester (1.79\%), benzene methanol (1.59\%), Cycloheptasiloxane,tetradecamethyl (1.38\%), Z, Z- 3, 13- octadecadien-1- ol (1.31\%), 2pentadecanone (1.27\%), 1-methylbicyclo [4.1.0] heptanes 1-methylnorcarane (1.06\%), L- linalool (1.04\%), cyclohexene (1.03\%) and methyl jasmonate $(0.94 \%)$ as main parts. 
Table 8. Compounds present in the Ficus sycamorus fruits using GC-MS analysis

\begin{tabular}{|c|c|c|c|c|}
\hline Peak name & Retention time & Formula & MW & \% Peak area \\
\hline $\begin{array}{l}\text { Ambrosiol (8,9-dihydroxy-6,9a-dimethyl-3-methylidene-decahydro- } \\
\text { azuleno[4,5-b]furan-2(3h)-one) }\end{array}$ & 2.497 & $\mathrm{C}_{15} \mathrm{H}_{22} \mathrm{O}_{4}$ & 266.34 & 30.64 \\
\hline N-Methyl-2-chloropyrrole & 5.01 & $\mathrm{C}_{5} \mathrm{H}_{6} \mathrm{ClN}$ & 115.56 & 5.04 \\
\hline 4-Amino-3,5-di-2-pyridyl-4H-1,2,4-triazole & 4.293 & $\mathrm{C}_{12} \mathrm{H}_{10} \mathrm{~N}_{6}$ & 238.25 & 5.07 \\
\hline 2-Methylpyrrole-3-carbonitrile & 7.031 & $\mathrm{C}_{6} \mathrm{H}_{6} \mathrm{~N}_{2}$ & 112.13 & 7.06 \\
\hline 1,4-Cyclohexanedione & 7.675 & $\mathrm{C}_{6} \mathrm{H}_{8} \mathrm{O}_{2}$ & 106.13 & 4.71 \\
\hline 2-Isopropyl-1,3-dioxolane & 8.166 & $\mathrm{C}_{6} \mathrm{H}_{12} \mathrm{O}_{2}$ & 116.16 & 5.86 \\
\hline Phenyltrihydrosilane & 8.255 & $\mathrm{C}_{6} \mathrm{H}_{5} \mathrm{SiH}_{3}$ & 108.21 & 3.91 \\
\hline Ethanone, 1-(2-methyl-1-cyclopenten-1-yl) & 9.165 & $\mathrm{C}_{8} \mathrm{H}_{12} \mathrm{O}$ & 124.18 & 4.07 \\
\hline Methyl ester of gibberellin A5 & 9.261 & $\mathrm{C}_{20} \mathrm{H}_{24} \mathrm{O}_{5}$ & 344.40 & 4.38 \\
\hline Benzene, 1,4-dimethyl-2,5-bis(1-methylethyl) & 14.81 & $\mathrm{C}_{14} \mathrm{H}_{22}$ & 190.33 & 1.29 \\
\hline 2,4-Di-tert-butylphenol & 15.099 & $\mathrm{C}_{14} \mathrm{H}_{22} \mathrm{O}$ & 206.33 & 22.66 \\
\hline $\begin{array}{l}\text { Phenyl 4-[bis(ethoxycarbonyl)but-3-ynyl]-2,3,4-trideoxy-alpha.,L- } \\
\text { glcero-pent-2- }\end{array}$ & 22.443 & $\mathrm{C}_{21} \mathrm{H}_{26} \mathrm{O}_{5}$ & 374.00 & 5.31 \\
\hline
\end{tabular}

Table 9. Compounds present in the Ficus sycamorus leaves using GC-MS analysis

\begin{tabular}{|c|c|c|c|c|}
\hline Peak name & Retention time & Formula & MW & \% Peak area \\
\hline Gamma-Undecalactone & 2.754 & $\mathrm{C}_{1} \mathrm{H}_{22} \mathrm{O}_{2}$ & 184.8 & 9.87 \\
\hline 2-Ethylcyclohexyl 3-chloropropanoate & 4.232 & $\mathrm{C}_{11} \mathrm{H}_{19} \mathrm{ClO}_{3}$ & 218.72 & 6.29 \\
\hline 2-Ethylcyclohexyl bromoacetate & 5.067 & $\mathrm{C}_{10} \mathrm{H}_{1}-\mathrm{BrO}_{2}$ & 249.15 & 1.62 \\
\hline Aspidocarpine & 5.432 & $\mathrm{C}_{22} \mathrm{H}_{30} \mathrm{~N}_{2} \mathrm{O}_{3}$ & 370.49 & 2.69 \\
\hline 5-(1-Hydroxy-2-propanyl)-2-methylcyclohexanol & 6.145 & $\mathrm{C}_{10} \mathrm{H}_{20} \mathrm{O}_{2}$ & 172.27 & 16.67 \\
\hline 2,7-Anhydro-l-galacto-heptulofuranose & 7.511 & $\mathrm{C}_{7} \mathrm{H}_{12} \mathrm{O}_{6}$ & 192.17 & 3.98 \\
\hline 1,5-Naphthalenediol & 7.824 & $\mathrm{C}_{10} \mathrm{H}_{8} \mathrm{O}$ & 160.17 & 2.02 \\
\hline Thiosulfuric Acid & 9.241 & $\mathrm{H}_{2} \mathrm{~S}_{2} \mathrm{O}_{3}$ & 114.13 & 5.12 \\
\hline Quinic acid & 9.406 & $\mathrm{C}_{7} \mathrm{H}_{12} \mathrm{O}_{6}$ & 192.17 & 1.13 \\
\hline$\alpha$-D-Glucopyranoside de $\alpha$-D-glucopyranosyl-(1->3)- $\beta$-D-fructofuranosyle, hydrate & 9.554 & $\mathrm{C}_{18} \mathrm{H}_{34} \mathrm{O}_{17}$ & 522.45 & 0.26 \\
\hline O-Benzyl-L-serine & 9.667 & $\mathrm{C}_{10} \mathrm{H}_{13} \mathrm{NO}_{3}$ & 195.22 & 1.63 \\
\hline 4-Allyl-2,6-dimethoxyphenol & 9.989 & $\mathrm{C}_{11} \mathrm{H}_{14} \mathrm{O}_{3}$ & 194.23 & 0.61 \\
\hline [1,1'-Bicyclopropyl]-2-octanoic acid, 2'-hexyl-, methyl ester & 10.372 & $\mathrm{C}_{21} \mathrm{H}_{38} \mathrm{O}_{2}$ & 322.53 & 0.32 \\
\hline Nalidixic Acid & 10.998 & $\mathrm{C}_{12} \mathrm{H}_{12} \mathrm{~N}_{2} \mathrm{O}_{3}$ & 232.24 & 0.72 \\
\hline D-chiro-Inositol, 3-O-(2-amino-4-((carboxyiminomethyl)amino)-2,3,4,6-tetradeoxy- & 11.241 & $\mathrm{C}_{14} \mathrm{H}_{25} \mathrm{~N}_{3} \mathrm{O}_{9}$ & 379.363 & 1 \\
\hline Neo Inositols & 11.372 & $\mathrm{C}_{6} \mathrm{H}_{12} \mathrm{O}_{6}$ & 180.16 & 3.4 \\
\hline Psoralene & 11.902 & $\mathrm{C}_{11} \mathrm{H}_{6} \mathrm{O}_{3}$ & 186.17 & 25.32 \\
\hline Phytol, acetate & 12.694 & $\mathrm{C}_{22} \mathrm{H}_{42} \mathrm{O}_{2}$ & 338.58 & 0.52 \\
\hline 6-(3-Hydroxy-but-1-enyl)-1,5,5-trimethyl-7-oxabicyclo[4.1.0]heptan-2-ol & 12.85 & $\mathrm{C}_{13} \mathrm{H}_{22} \mathrm{O}_{3}$ & 226.31 & 0.28 \\
\hline Methyl Palmitate & 13.241 & $\mathrm{C}_{17} \mathrm{H}_{34} \mathrm{O}_{2}$ & 270.46 & 3.88 \\
\hline Palmitic Acid & 13.711 & $\mathrm{C}_{16} \mathrm{H}_{32} \mathrm{O}_{2}$ & 256.43 & 1.03 \\
\hline Methyl (11E,14E)-octadeca-11,14-dienoate & 15.033 & $\mathrm{C}_{19} \mathrm{H}_{34} \mathrm{O}_{2}$ & 294.48 & 0.54 \\
\hline Methyl Linolenate & 15.12 & $\mathrm{C}_{19} \mathrm{H}_{32} \mathrm{O}_{2}$ & 292.46 & 2.3 \\
\hline Phytol & 15.268 & $\mathrm{C}_{20} \mathrm{H}_{40} \mathrm{O}$ & 296.54 & 1.62 \\
\hline Methyl isostearate & 15.441 & $\mathrm{C}_{19} \mathrm{H}_{38} \mathrm{O}_{2}$ & 298.51 & 0.76 \\
\hline Linoleoyl chloride & 15.572 & $\mathrm{C}_{18} \mathrm{H}_{31} \mathrm{OCl}$ & 298.89 & 0.37 \\
\hline cis-5,8,11,14,17-Eicosapentaenoic acid & 15.798 & $\mathrm{C}_{20} \mathrm{H}_{30} \mathrm{O}_{2}$ & 302.45 & 0.87 \\
\hline Quercetin 7,3',4'-Trimethoxy & 18.25 & $\mathrm{C}_{18} \mathrm{H}_{16} \mathrm{O}$ & 344.32 & 1.48 \\
\hline Lupeol & 35.251 & $\mathrm{C}_{30} \mathrm{H}_{50} \mathrm{O}$ & 426.73 & 3.7 \\
\hline
\end{tabular}

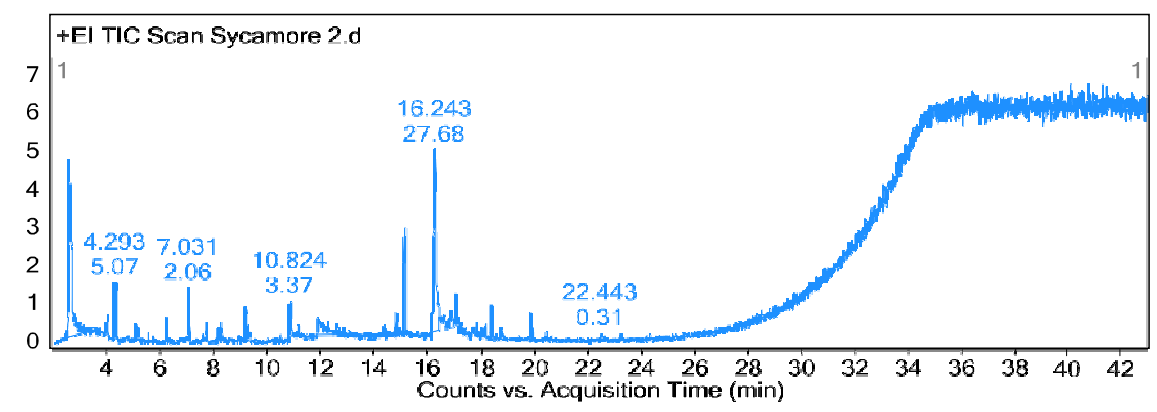

Fig. 1. GC-MS profiles of Ficus sycomorus fruits 
502

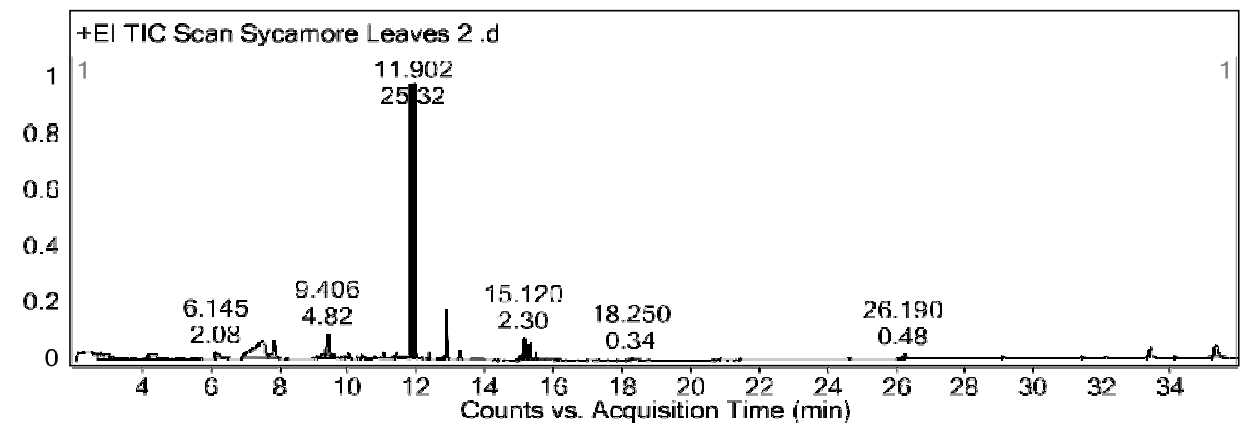

Fig. 2. GC-MS profiles of Ficus sycomorus leaves

GC- mass identified palmitic acid in leaves extract of ficus. Palmitic acid can be an antioxidant, hypocholesterolemic, nematicide, pesticide, lubricant (Praveen et al., 2010). Also, Phytol, a bioactive principle, is also found to give effective preventive and therapeutic results against arthritis. The reactive oxygen speciespromoting substances like phytol constitute a promising novel class of pharmaceuticals for the treatment of rheumatoid arthritis and possibly other chronic inflammatory diseases (Ogunlesi et al., 2009). Phytol was noted to possess antibacterial activities against Staphylococcus aureus by inflicting harm to cell membrane as a result, there is a leakage of potassium ions from bacterial cells. In addition, some constituents are active for some diseases. Psoralen was reported to be inhibitory on tumor cells (Okuyama et al., 1991).

\section{Conclusions}

This research is following a trend to effectively identify various compounds found in the ethanolic extract of fruits and leaves of Ficus sycomorus and finds its prophylactic role in designing and developing pharmacological drugs with fewer side effects. In vitro investigations in the present study provide substantial evidence that Ficus sycomorus leaves; an inedible waste product is a potent source of antioxidant, antimicrobial agent and anticancer activity thereby indicating its use as a value-added component for functional. In addition, F. sycomorus can be used as a source of natural antioxidants, which can be used as nutraceuticals to promote health, as preservatives to delay peroxidation of foods, and as flavoring for packed foods.

\section{References}

AbdEl-Rahman SS, Mazen MM, Mohamed HI, Mahmoud NM(2012). Induction of defense related enzymes and phenolic compounds in lupine (Lupinus albus L.) and their effects on host resistance against Fusarium wilt. European Journal Plant Pathology 134(1):105-116.

Abdel-Hameed El-SS (2009). Total phenolic contents and free radical scavenging activity of certain Egyptian Ficus species leaf samples. Food Chemistry 114(4):1271-1277.

Abdel-Rahim EA, El-Beltagi HS (2010). Constituents of apple, parsley and lentil edible plants and their therapy treatments for blood picture as well as liver and kidneys functions against lipidemic disease. EJEAFChe
$9(6): 1117-1127$.

Afify AEMMR, El-Beltagi HS, Fayed SA, El-Ansary AE (2018). Beneficial and potent effect of olive leaves extract on hyperglycemic state, kidney and liver function in STZ-induced type 2 diabetes mellitus. Fresenius Environmental Bulletin 27(5A):3733-3739.

Ahmed FA, Ragaa OO, Khalil FA (1986). Biochemical studies of the effect of growth regulator on safflower plant. Grasasy Aceites 37:68-71.

Aiyelaagbe O, Osamudiamen PM (2009). Phytochemical screening for active compounds in mangifera indica leaves from Ibadan, Oyo State. Plant Sciences Research 1(2):11-13.

Akinpelu DA, Aiyegoro OA, Okoh AI (2008). In vitro antibacterial and phytochemical properties of crude extract of stem bark of Afzelia africana (Smith). African Jounal of Biotechology 7(20):3662-3667.

Al-mataniSK, Al-Wahaibi RNS, Hossain MA (2015).In vitro evaluation of the total phenolic and flavonoid contents and the antimicrobial and cytotoxicity activities of crude fruit extracts with different polarities from Ficus sycomorus. Pacific Science Review A: Natural Science and Engineering 17(3):103-108.

Ao C, Li A, Elzaawely AA, Xuan TD, Tawata S (2008). Evaluation of antioxidant and antibacterial activities of Ficus microcarpa L. fil. extract. Food Control 19(10):940-948.

AOAC (2000). Official Methods of Analysis of the Association of Official Analytical Chemists, $17^{\text {th }}$ edn (edited by W. Horwitz) Washington, DC.

Arima H, Ashida H, Danno G (2002). Rutin-enhanced antibacterial activities of flavonoids against Bacillus cereus and Salmonella enteritidis. Bioscience Biotechnology and Biochemistry 66(5):1009-1014.

Bagavathi PE, Ramasamy N (2012). GC-MS analysis of phytocomponents in the ethanol extract of Polygonum chinense L. Pharmacognosy Research 4(1):11-14.

Bauer AW, Kirby WM, Sherris JC, Turck M (1966). Antibiotic susceptibility testing by a standardized single disk method. American Journal of Clinical Pathology 45(4):493-496.

Bello OM, Gafar MK, Haruna A, Zack AM (2013). In vivo toxicity studies and phytochemeical screening of steam bark of Ficus sycomorus Linn (Moraceae). Asian Journal ofScience and Technology 4(12):45-47.

Bello OM, Ojediran OJ, Dada OA, Olatunya AM, Awakan OJ (2015). Invivo toxicity studies and phytochemical screening of stem bark of Ficus sycomorus Linn (Moraceae). Journal of Environmental Science, Toxicology and Food Technology 9(3):72-74. 
Blasiak J, Trzeciak A, Gasiorowska A, DrzewoskiJ, Maiecka-PanasE (2002). Vitamin $\mathrm{C}$ and quercetin modulate DNA-damaging effect of $\mathrm{N}$ methyl-N-nitrosoguanidine. Plant Food for Human Nutrition 57(1):53-61.

Braide W, Dokubo KO, Adeleye SA, Uzoh CV, Akobundu CI (2018). Phytochemical properties, toxicological screening and antibacterial qualities of various parts extract of Ficus sycomorus. Journal of Medicinal Plant and Herbal Therapy Research 6:1-8.

Bruneton J (2009). Menthe in: pharmacognosie, phytochimie, plantes médicinales ( $4^{\text {th }}$ edn).Lavoisier Tec \& Doc, Paris, pp 631-638.

Cabeza M, Bratoeff E, Heuze I, Ramírez E, Sanchez M, Flores E (2003). Effect of $\beta$-sitosterol as inhibitor of $5 \alpha$-reductase in hamster prostate. Proceedings of the Western Pharmacology Society 46:153-155.

Chew YL, Lima YY, Omara M, Khoab KS (2008).Antioxidant activity of three edible seaweeds from two areas in South East Asia. LWT-Food Science and Technology 41(6):1067-1072.

Chou HJ, Kuo JT, Lin ES (2009). Comparative antioxidant properties of water extracts from different parts of beefsteak plant (Perilla frutescens). Journal of Food and Drug Analysis 17(6):489-496.

Cuvelier ME, Richard H, Berset C (1992). Comparison of the antioxidative activity of some acid-phenols: structure-activity relationships. Bioscience, Biotechnology, and Biochemistry 56(2):324325.

Daniel D, Dluya T (2016). In vitro biochemical assessments of methanol stem bark extracts of Ficus sycomorus plant. Jordan Journal of Biological Sciences 9(1):63-68.

Denwick PM (2002). Natural products: a biosynthetic approach. 2nd Edn., John Wiley and Sons, Ltd., England, pp 241-243.

El-Beltagi HES (2011). Effect of roasting treatments on protein fraction profiles, some enzyme activities of Egyptian peanuts. International Journal of Food Science and Nutrition 62(5):453-456.

El-Beltagi HS, Mohamed HI, Megahed BMH, Gamal M, Safwat G(2018). Evaluation of some chemical constituents, antioxidant, antibacterial and anticancer activities of Beta vulgaris L. root. Fresenius Environmental Bulletin 27(9):369-6378.

El-Sayed MM, Mahmoud M AA, EINahas HAK, El-Toumy SAH, ElWakil EA, Ghareeb MA (2010) Bio-guided isolation and structure elucidation of antioxidant compounds from the leaves of Ficus sycomorus. Pharmacologyonline 3:317-332.

Gordon MH (1990). The mechanism of antioxidant action in vitro. In: Hudson BJF, ed. Food antioxidants. Elsevier Applied Food Science Series. Springer Netherlands, pp 1-18.

Goupy P, Hugues M, Biovin P, Amiot MJ (1999). Antioxidant composition and activity of barley (Hordeum vulgare) and malt extracts and of isolated phenolic compounds. Journal of the Science of Food and Agriculture 79(12):1625-1634.

Hae-Ryong P, Eunju P, A-Ram R, Kyung-Im J, Ji-Hwan H, Seung-Cheol L (2006). Antioxidant activity of extracts from Acanthopanax senticosus. African Journal of Biotechnology 5(23):2388-2396.

Harborne JB (1998). Phytochemical methods: a guide to modern techniques of plant analysis. 2nd ed., Chapman and Hall, London, pp 5484 .

Hassan S, Lawal M, Muhammad B, Umar R (2007). Effects of anthraquinone gycosides and aqueous ethanol extracts of Ficus sycomorus L. (Moraceae) on rat liver and kidney functions. Asian Journal of Biochemistry 2(2):136-141.

Hodek P, Trefil P, Stiborova M (2002). Flavonoids-potent and versatile biologically active compounds interacting with cytochrome. ChemicoBiological Interactions 139(1):1-21

Ibrahim G, Mahmud N, Yaro AH, Ahmed A (2000). Phytochemical and toxicity evaluation of the stem bark of Ficus sycomorus Linn (Moraceae). Biological and Environmental Sciences Journal for the Tropics 3:37-40.

Ivanov I, Dincheva I, Badjakov I, Petkova N, Denev P, Pavlov A (2018). GC-MS analysis of unpolar fraction from Ficus carica L. (fig) leaves. International Food Research Journal 25(1):282-286.

Jiang ST, Shaol P, Pan LJ, Zhao YY. (2006). Molecular distillation for recovering tocopherol and fatty acid methyl esters from rapeseed oil. Deodoriser Distillate Biosystems Engineering93(4):383-391.

Joseph B, Raj SJ (2011). Pharmacognostic and phytochemical properties of Ficus carica Linn-an overview. International Journal of Pharmtech Research 3(1):8-12.

Kamel JM (1991). An extract of the mesocarps offruits of Balanite aegyptiaca exhibited prominent antidiabetic properties in mice. Chemical and Pharmaceutical Bulletin 39:1229-1233.

Kazlowska K, Lin HTV, Chang SH, Tsai GJ (2013). In vitro and in vivo anticancer effect of sterol fraction from red algae Porphyra dentate. Evidence-Based Complementary and Alternative Medicine 1-10.

Kesba HH, El-Beltagi HS (2012). Biochemical changes in grape rootstocks resulted from humic acid treatments in relation to nematode infection. Asian Pacific Journal of Tropicl Biomedicin 2(4):287-293.

Kobeasy MI, El-Beltagi HS, El-Shazly MA, Khattab EA (2011). Induction of resistance in Arachis hypogaea $\mathrm{L}$. against peanut mottle virus by nitric oxide and salicylic acid. Physiological and Molecular Plant Pathology 76(2):112-118.

Kumawat BK, Gupta M, Tarachand SY (2012). Free radical scavenging effect of various extracts of leaves of Balanite aegyptica (L.) delile by DPPH method. Asian Journal of Plant Science and Research 2(3):323329.

Lansky EP, Paavilainen HM, Pawlus AD Newman RA (2008). Ficus spp: ethnobotany and potential as anticancer and antiinflammatory agent. Journal of Ethnopharmacology 119(2):195-213.

Lee J, Durst RW, Wrolstad RE (2005). Determination of total monomeric anthocyanin pigment content of fruit juices, beverages, natural colorants, and wines by the $\mathrm{pH}$ differential method: collaborative study.Journal of AOAC International 88(5):1269-1278.

Lopez D, Pavelkova M, Gallova L, Simonetti P, Gardana C (2007). Dealcoholized red and white wines decrease oxidative stress associated with inflammation in rats. British Journal of Nutrition 98(3):611-619.

MacKay DS, Jones PJH (2011). Phytosterols in human nutrition: type, formulation, delivery, and physiological function. European Journal of Lipid Science and Technology 113(12):1427-1432.

Manimozhi DM, Sankaranarayanan S, Kumar GS (2012). Effect of different extracts of stem bark of Ficus sp. on multidrug resistant pathogenic bacteria. International Journal of Pharmaceutical Sciences andResearch 3(7):2122-2129. 
504

MarkP (1998). Antioxidants. Clinical Nutrition Insights 31:01-04.

Mattila P, Astola J, Kumpulainen J (2000). Determination of flavonoids in plant material by HPLC with diode-array and electro-array detections. Journal of Agriculture and Food Chemistry 48(12):58345841.

Menon LG, Kuttan R, Kuttan G (1995) Inhibition of lung metastasis in mice induced by B16F10 melanoma cells by polyphenolic compounds. Cancer Letters 95(1-2):221-225

MohamedZM, Salem AZ, Salem M, Camacho LM, Hayssam MA (2013). Antimicrobial activities and phytochemical composition of extracts of Ficus species: an overview. African Journal of Microbiology Research 7(33):4207-4219

Mousa O, Vuorela P, Kiviranta J, Wahab SA, Hiltohen R, Vuorela H (1994). Bioactivity of certain Egyptian Ficus species. Planta Medica 58(S1):632-633.

MudiSY, Muhammad A, Musa J, DattiY(2015). Phytochemical screening and antimicrobial activity of leaves and fruits extract of Ficus sycomorus. ChemSearch Journal 6(1):62-67.

Nobori T, MiurakK, Wu DJ,Lois A, TakabayashikDA (1994).Deletion of the cyclin-dependent kinase- 4 inhibitor gene in multiple human cancers. Nature 368(6473):753-756.

Ogunlesi M, Okiei W, Ofor E, Osibote AE (2009). Analysis of the essential oil from the dried leaves of Euphorbia hirta Linn (Euphorbiaceae), a potential medication for asthma. African Journal of Biotechnology 8(24):7042-7050.

Ogunleye DS, Ibitoye SF (2003). Studies of antimicrobial activity and chemical constituents of Ximenia americana. Tropical Journal of Pharmaceutical Research 2(2):239-241.

Okuyama T, Takata M, Takayasu J, Hasegawa T, Tokuda H, et al, Iwashima A (1991). Anti-tumor-promotion by principles obtained from Angelica keiskei. Planta Medica 57(3):242-246.

OkwuDE (2001). Phytochemicals and vitamin content of indigenous spices of Southeastern Nigeria. Journal for Sustaining Agricultural Environment 6(1):30-37.

Pejin B, Savic A, Sokovic M, Glamodija J, Ciric A, et al, Mojovic M (2014). Further in vitro evaluation of antiradical and antimicrobial activities of phytol. Natural Product Research 28(6):372-376.

Praveen KP, Kumaravel S, Lalitha C (2010). Screening of antioxidant activity, total phenolics and GC-MS study of Vitex negundo. African Journal of Biochemistry Research 4(7):191-195.

Prieto JM, Recio MC, Giner RM (2006). Anti-inflammatory activity of $\beta$ sitosterol in a model of oxazolone-induced contact-delayed-type hypersensitivity. Boletín Latinoamericano y del Caribe de Plantas Medicinalesy Aromáticas 5(3):57-62.

Prior RL, Wu X, Schaich K (2005). Standardized methods for the determination of antioxidant capacity and phenolics in foods and dietary supplements. Journal of Agricultural Food Chemistry 53(10):42904302.

Ramde-Tiendrebeogo A, Tibiri A, Hilou A, Lompo M, et al., Millogo-Kone $H$ (2012). Antioxidant and antibacterial activities of phenolic compounds from Ficus sur Forssk and Ficus sycomorus L. (Moraceae): potential for sickle cell disease treatment in Burkina Faso. International Journal of Biology and Chemical Science 6(1):328-336.
Rauha JP, Remes S, Herinonen W, Hopia M, Kgjala T, et al., Pitinlaja K (2000). Antimicrobial effects of finished plant extract containing flavanoids and other phenolic compounds. International Journal of Food Microbiology 56(1):3-12.

Reiffel JA, McDonald A (2006). Antiarrhythmic effects of omega-3 fatty acids. American Journal of Cardiology 98(4):50-60.

Repetto G, del Peso A, Zurita JL (2008). Neutral red uptake assay for the estimation of cell viability/cytotoxicity. Nature Protocols 3(7):11251131.

Rodriguez J, Yáñez J, Vicente V, Alcaraz M, et al, Benavente-García O (2002). Effects of several flavonoids on the growth of B16F10 and SKMEL- 1 melanoma cell lines: relationship between structure and activity. Melanoma Research 12(2):99-107.

Romeh AA (2013). Phytochemicals from Ficus sycomorus L. leaves act as insecticides and acaricides. African Journal of Agricultural Research 8(27):3571-3579.

Sandabe K, Onyeyili PA, Chibuzo GA (2006). Phytochemical screening and effect of aqueous extract of Ficus sycomorus L. (Moraceae) stembark on muscular activity in laboratory animals. Journal of Ethnopharmacology 104(1-2):283-285.

Sandabe UK, Abdurrahaman F, Goniri B, Baba U (2007). The combined effects of aqueous extract of Ficus sycomorus. (Moraceae) stem and Nigella sativa. (Ranuncualaceae) seeds of hematological and biochemical parameters in rabbits. Animal Research International 4(3):753-757.

Saxena V, Mishra G, Saxena A, Vishwakarma KR (2013). A comparative study on quantitative estimation of tannins in Terminalia chebula, Terminalia belerica, Terminalia arjuna and Saraca indica using spectrophotometer. Asian Journal of Pharmaceutical and Clinical Research 6(3):148-149.

Scalbert A (1991). Antimicrobial properties of tannins. Phytochemistry 30(12):3875-3883.

Seeram NP, Adams LS, Hardy ML, Heber D (2004) Total cranberry extract versus its phytochemical constituents: antiproliferative and synergistic effects against human tumor cell lines. Journal of Agricultural and Food Chemistry 52(9):2512-7.

Seidel V, Taylor PW (2004). In-vitro activity of extracts and constituents of Pelagonium against rapidly growing mycobacteria. International Journal of Antimicrobial Agents 23(6):613-619.

Shallan MA, El-Beltagi HS, Mona AM, Amera TM, Sohir NA (2010). Effect of amylose content and pre-germinated brown rice on serum blood glucose and lipids in experimental animal. Australian Journal of Basic and Applied Sciences 4(2):114121.

Sheba DW, Saxena RK, Gupta R(1999). The fungistatic action of oleic acid. CurrentScience 76:1137-1140.

Singleton V, Rossi J (1965). Colorimetry of total phenolics with phosphomolibdic-phosphotungstic acid reagents. The American Journal of Enologyand Viticulture 16(3):144158.

Soonham Y (2015). Genotoxicity and carcinogenicity of alkaloids of Rhazya stricta. LAP Lambert Academic Publishing, Germany, pp 152.

Sumathy N, SumathyJ (2011). Antibacterial and antifungal activity of musa fruit peels against skin and gastrointestinal tract diseases. Herbal Tech Industry 2:9-11. 
Tim-Cushnie TP (2014). Alkaloid: an overview of their antibacterial, antibiotic enhancing and antivirulence activities International Journal of Antimicrobial Agents 4(5):377-386.

Van NS, Gardiner A, Tolley K (2007). New records of Ficus (Moraceae) species emphasize the conservation significance of inselbergs in Mozambique.South Africa Journal of Botany 73(4):642-649.

Vogel AI (1975). A textbook of practical organic chemistry. 3rd Ed, Longman, Group Limited London.

Ward OP, Singh A (2005). Omega-3/6 fatty acids: alternative sources of production. Process Biochemistry 40(12):3627-3652.

You BR, Park WH (2010) Gallic acid-induced lung cancer cell death is related to gutathione depletion as well as reactive oxygen species increase. Toxicology in Vitro 24(5):1356-1362.
Zaku S, Abdulrahama F, Onyeyili P, Aguzue O, Thomas S (2009). Phytochemical constituents and effects of aqueous root-bark extract of Ficus sycomorus L. (Moracaea) on muscular relaxation, anaesthetic and sleeping time on laboratory animals. African Journal of Biotechnology 8(21):329-337.

Zhishen J, Mengcheng T, Jianming W (1999). The determination of flavonoid contents in mulberry and their scavenging effects on superoxide radicals. Food Chemistry 64(4):555-559. 